\title{
Cultural explanations for racial and ethnic stratification in academic achievement: a call for a new and improved theory.
}

\section{Citation}

Warikoo, Natasha, and Prudence Carter. 2009. Cultural explanations for racial and ethnic stratification in academic achievement: a call for a new and improved theory. Review of Educational Research 79, no. 1:366-394.

\section{Published Version}

http://rer.sagepub.com/content/79/1/366.abstract

\section{Permanent link}

http://nrs.harvard.edu/urn-3:HUL.InstRepos:23922471

\section{Terms of Use}

This article was downloaded from Harvard University's DASH repository, and is made available under the terms and conditions applicable to Other Posted Material, as set forth at http:// nrs.harvard.edu/urn-3:HUL.InstRepos:dash.current.terms-of-use\#LAA

\section{Share Your Story}

The Harvard community has made this article openly available.

Please share how this access benefits you. Submit a story.

\section{Accessibility}




\title{
Cultural Explanations for Racial and Ethnic Stratification in Academic Achievement: A Call for a New and Improved Theory
}

\author{
Natasha Warikoo \\ Prudence Carter
}

\begin{abstract}
In this article we assess the literature on cultural explanations for ethno-racial differences in K-12 schooling and academic performance. Some cultural arguments problematically define certain ethno-racial identities and cultures as subtractive from the goal of academic mobility, while simultaneously defining the ethnic cultures and identities of others as additive and oriented towards this goal. We review two prevailing schools of thought that compare immigrant and native minority students: cultural ecological theory (CET) and segmented assimilation theory. Second, we examine empirical research that highlights the complexity of culture, focusing on four domains: (1) the school's cultural ethos; (2) variation in identities and cultural practices within ethnic and racial groups; (3) the multidimensional nature of culture and its variable impact on students; and (4) the intersections of race, ethnicity, class, and gender. This literature - when synthesizedsuggests that a coherent theory of culture's impact on ethnic and racial differences in schooling outcomes must unpack the multiple influences of identity and context more deliberately than previous literature has done. Finally, we call for studies that employ comparative research across groups and treat race and ethnicity as dependent rather than independent variables, thereby equipping researchers with the tools to better explain how culture influences schooling and achievement.
\end{abstract}


"Cultural Explanations for Racial and Ethnic Stratification in Academic Achievement: A Call for a New and Improved Theory”

It is rare to read any piece of research in race, ethnicity, and education nowadays that does not refer to the "academic achievement gap.” Myriad reports, books, and articles provide evidence of significant differences in test scores, high school completion rates, course selection, college attainment and other educational outcomes that exist between students of various racial and ethnic minority groups and their white counterparts (Ferguson, 2001; Jencks \& Phillips, 1998; Kao \& Thompson, 2003; National Center for Education Statistics, 2001, 2007). ${ }^{1}$ The gap also constitutes the basis of a major U.S. educational policy, the No Child Left Behind Act (NCLB), which became the first piece of federal legislation on education to require schools to disaggregate data on academic achievement by race. Ladson-Billings (2006) notes that the gap is a major byproduct of an "education debt" - the accumulation of multiple decades of past economic, political, and educational neglect. Historically, various racial and ethnic minority groups have confronted discrimination and marginalization in schools. Still, studies show that certain immigrant minority groups (e.g., Chinese Americans, Korean Americans, and South Asian Americans) fare better academically than many other racial and ethnic groups (e.g., African Americans, Mexican Americans, and Native Americans) (Donahue, Voelkl, Campbell, \& Mazzeo, 1999; Kao \& Thompson, 2003; Kasinitz, Mollenkopf, Waters, \& Holdaway, 2008; Knapp, 2005). Since the former outperform groups of students who are the descendants of slaves or colonized peoples, the ensuing logic is that there must be something either group-specific or cultural that explains these differences. 
Cultural arguments that have come to dominate the field problematically define specific ethno-racial identities as subtractive from the goal of academic mobility, while simultaneously defining the ethnic cultures and identities for select immigrant groups as additive and oriented towards this goal. ${ }^{2}$ As we discuss further below, for African Americans in particular, the literature largely emphasizes the anti-achievement orientation of a monolithic "black” culture (e.g., Fordham \& Ogbu, 1986; McWhorter, 2001), which when characterized appears to describe a culture endemic to resistant or rebellious youth who engage in downwardly-mobile behaviors (for a similar critique, see O'Connor, Lewis, \& Mueller, 2007). In contrast, for some immigrant minority groups, the literature links ethnic culture with specific parental influences and outlooks predicated on evidence of strong family and cultural values toward hard work, effort, and achievement (Caplan, Choy, \& Whitmore, 1991; Gibson, 1988; Louie, 2004; Zhou \& Bankston, 1998). The characterizations of ethno-racial cultures vary, as a result, depending on the group. That is, African American cultures are infantilized through the depiction of school negative youth as the primary cultural producers. These youth are thought to exhibit particular shared practices, tastes, or other behaviors that have an adverse impact on their and others' academic well-being or social attainment (Fordham, 1996; Fordham \& Ogbu, 1986; Lewis, 1969; Ogbu \& Simons, 1998). Yet, for many first and second generation immigrant minority students, culture is depicted with relatively more maturity, defined by values and beliefs stemming from the strong influence of hardworking immigrant parents (for a similar discussion, see Slaughter-Defoe, Nakagawa, Takanishi, \& Johnson, 1990). What becomes apparent in a review of the literature is that 
analysts shift developmental perspectives when they relate culture to high achieving versus low achieving minority students’ educational experiences.

Before we proceed, allow us to clarify our usage of terms. In this discussion, "native minority" denotes nativity, referring specifically to minority students of African American, Native American, Puerto Rican and Mexican American heritages, whose fore parents are either indigenous or were forcefully incorporated via slavery or conquests into what has become known as the United States. "Immigrant minority" primarily refers to those students whose parents or grandparents emigrated from Africa, Asia, the Caribbean, and Latin America through the most recent immigration flows to the United States (i.e., post-1965). We acknowledge that much heterogeneity exists among so-called native and immigrant minority students, recognizing that not all students in either category conform to the dominant narratives about their respective groups (Ngo \& Lee, 2007; O'Connor, Lewis, \& Mueller, 2007). We use these terms primarily as heuristics and as markers of the differential social and educational experiences of minority students.

Our intent in this review essay is twofold: (1) to illuminate how culture is deployed in educational research to explain disparate achievement outcomes between ethno-racial groups and (2) to discuss the multiple dimensions of group membership with respect to culture in schools for native and immigrant minority students. The review also discusses some of the problems in the literature premised on racialized oppositional cultures. In this appraisal of studies in the fields of anthropology, cultural studies, economics, education, and sociology (both of our disciplinary homes), we examine empirical research that highlights the complexity of culture, focusing on four domains: (1) the school's cultural ethos; (2) variation in identities and cultural practices within ethnic and racial groups; (3) 
the multidimensional nature of culture and its variable impact on students; and (4) the intersections of race, ethnicity, class, and gender. This literature-when synthesizedsuggests that a coherent theory of culture's impact on ethnic and racial differences in schooling outcomes must unpack the multiple influences of identity and context more deliberately than previous literature has done. Lastly, we construct an argument that calls for a multi-leveled conceptualization of the links between culture and racial and ethnic stratification in achievement. We end by suggesting new directions for research on the connections among race, ethnicity, culture and achievement. Note that due to space limitations we focus solely on cultural explanations; we do not address the vast and significant literature on the structural influences on educational stratification by race and ethnicity.

\section{The Origins of the Debate on Culture and Achievement}

As Ward Goodenough described decades ago: “culture consists of whatever it is one has to know or believe in order to operate in a manner acceptable to its members... It is rather an organization of these things. It is the form of things that people have in mind, their models for perceiving, relating, and otherwise interpreting them” (as quoted in Keesing, 1974, p. 77). More specifically, culture inheres in practices and meanings shared by members of a particular social group, such as social actors, families, neighborhoods, communities, schools, organizations, and institutions. Culture is comprised of shared beliefs, behaviors, attitudes, and took-kits of "symbols, stories, rituals, and world-views” (Swidler, 1986); a variety of behaviors and styles, ranging from speech styles and language, to specific kinds of physical interaction, to tastes in music, 
clothing, and food, and other "symbolic” cues (Gans, 1979); and symbolic boundaries, or "conceptual distinctions made by social actors to categorize objects, people, practices, and even time and space,”(Lamont \& Molnár, 2002, page 168). ${ }^{3}$

Finally, a shared group identity—emerging from either a collective narrative or beliefs about shared historical experiences, social experiences, and/or ancestry— characterizes a dimension of culture as we employ it here (Cornell, 1994; Weber, 1968). Some scholars of Black education, for example, utilize the concept of a culture of the African Diaspora to signify the resources and orientations of peoples of African descent globally who share experiences of racism, discrimination, and educational disenfranchisement across the African Diaspora (King, 2005; Lee, 2005). However, not all individuals of particular ethnic or racial groups agree on what cultural practices or narratives define the group, and indeed collective ethnic and racial identities risk essentializing individuals (Appiah, 1996; Brubaker \& Cooper, 2000; Hollinger, 1995).

Early perspectives on culture and academic stratification emphasized the culture of schools as institutions, theorizing how schools reproduce class-based (and racial/ethnic) hierarchies in society (Bourdieu \& Passeron, 1977; Bowles \& Gintis, 1976). We discuss more recent formulations of social reproduction theory later in this paper. In response to this literature, later works in educational research allowed room for youth's agency by describing resistance in the school behaviors of certain youth in ways that impeded their academic achievement (Giroux, 1983; Hall \& Jefferson, 1976; MacLeod, 1995; Sewell, 1997; Willis, 1977). These theories criticized structuralists—who explain minority school disadvantage as a result of the limited availability of systemic educational resources such parental resources; lower teacher quality; and the socialization of such 
students to be compliant workers and laborers in a capitalist regime (Blau \& Duncan, 1967; Bowles \& Gintis, 1976)—for being overly deterministic, attaching little or no significance to any forms of opposition from subordinate groups.

Classic theories of resistance, which originated in Britain’s “Birmingham School” during the 1970s, described not ethnic and racial minorities but rather white, working class and poor youth (Hall \& Jefferson, 1976; Hebdige, 1979; Willis, 1977). Paul Willis’ (1977) seminal work, Learning to Labour: How Working Class Kids Get Working Class Jobs, laid the foundation for theories of oppositional cultures in Britain. In it, Willis suggested that the working class "lads" of a northern industrial English town inhabit a culture that at once resists class stratification while also reproducing it. Willis and his colleagues and later theorists (Giroux, 1983; Hall \& Jefferson, 1976; Sewell, 1997; Willis, 1977) attributed subversive motivations to behaviors that disrupt educational achievement and styles by working class (and, later, minority) youth. However, they did so without providing empirical evidence for deliberate, conscious motivations (Davies, 1995 and Mirza, 1999 make a similar argument). One possible explanation for these challenges of interpretations is that such research relies on an etic approach, where the analyst or research imposes meaning on the situation, versus an emic approach that relies on the individuals' being observed own meanings. US researchers have also been influenced by the British tradition of resistance theory (Giroux, 1983; MacLeod, 1995).

\section{A Cultural Ecology Theory}

As British scholars were developing theories of "resistance through rituals” (Hall \& Jefferson, 1976), across the Atlantic social scientists in the United States were 
developing cultural-ecological theories of educational stratification, in an attempt to integrate both cultural and structural approaches. In the US these theorists focused on ethno-racial stratification in education. In the late 1970s, cultural-ecological theory (CET) emerged as one of the most viable cultural explanations for ethno-racial differences in achievement. In a seminal book, Minority Education and Caste (1978), anthropologist John Ogbu linked historical and macro-social issues to divergences in achievement between those whom he referred to as "involuntary" or "caste-like" minorities, and "voluntary" minorities. Ogbu defined the former as the descendants of those incorporated into the United States via slavery, conquest, or colonization. Specifically, this group includes American Indians and Alaska natives, African Americans, early Mexican Americans in the U.S. Southwest, and Puerto Ricans (Ogbu, 1990, 1991; Ogbu \& Simons, 1998).

Voluntary minorities, in contrast, are the offspring of those who arrived at the borders and shores of the United States voluntarily, most in search of improved economic opportunities. Other minorities include refugees (predominantly from Southeast Asia), who are not categorized as voluntary immigrants but rather as persons who were forced to come to the U.S. as a result of political and/or economic crises in their places of origins. Ogbu and Simon (1998) argue that voluntary and refugee minorities who come with cultural and linguistic differences arrive in the US with a "tourist attitude": the idea that to succeed in this society they would have to learn to speak and behave like White Americans, although they manage their own cultural distinction. According to CET, "voluntary" minority students maintain more optimistic beliefs about their chances for success than their peers classified as “involuntary," "castelike” or 
"native” racial and ethnic minorities. Voluntary minorities believe that after a period of adaptation, they will self-advance. While they potentially face both cultural invisibility and conflict in classrooms, voluntary minorities will perform better than native minorities, since they take a relativist stance and perceive that their conditions are better than those in either their parents’ or their native lands.

Furthermore, the differences between these two groups, as CET explains, boil down to their socio-cultural responses to discrimination and cultural invisibility. This theory maintains that voluntary minority students see school success as a major means to upward mobility, believing that the strategies that hold for middle-class Whites hold for them, while involuntary minorities view the opportunity structure as primarily closed to them and their family members. That is, involuntary minorities render certain behaviors conducive to upward mobility as only beneficial to the White, middle class; hence, they culturally invert and embrace an oppositional culture.

For some so-called involuntary or native minorities in the United States, oppositional culture is discussed in the context of the popular resistance to "acting White" thesis. Specifically, Fordham and Ogbu (1986) have contended that Black youth resist "acting White" by avoiding or rejecting those social behavioral patterns that they associate with Whiteness_embracing the school curriculum, speaking Standard English, spending much time in the library, and getting good grades, for example. Consequently, they collude in their own academic underachievement. While involuntary minorities know what it takes to succeed in the academy, job markets and the polity, they refuse to fully embrace these behaviors because they feel 1) that these requirements are imposed on them by Whites; and 2) that their own cultural and language differences are markers of 
identity to be maintained and not to be overcome (Ogbu \& Simons, 1998). For over thirty years, the resistance to "acting White" thesis has emerged as one of the most popular cultural explanations for the ethno-racial academic achievement gap.

\section{Segmented Assimilation Theory}

Segmented assimilation theorists, accepting the basic premises of CET (specifically the oppositional culture frame), claim that proximity to native minority students threatens the educational achievement of immigrant youth (Portes \& Zhou, 1993). Alejandro Portes and Min Zhou’s model of segmented assimilation (1993) describes how new immigrant students of color have several trajectories of cultural adaptation: identifying with (1) the dominant group in the host society, (2) the native minority "underclass," or (3) their own ethnic immigrant communities. As does Ogbu, Portes and his colleagues frame their theory to integrate cultural and structural influences on the second generation. That is, neighborhood, racial status, labor market opportunities, parental education, and the overall context of reception are all thought to influence the mode of adaptation (Portes, Fernández-Kelly, \& Haller, 2005; Portes \& Rumbaut, 2001; Portes \& Zhou, 1993; Zhou, 1997). According to segmented assimilation theory, growing up in one's ethnic community_-even if disadvantaged—can lead to school success, while growing up and being educated among disadvantaged African Americans, for African American and second generation children alike, can lead to poor outcomes through the problems associated with ghetto poverty and disadvantage. In addition, they posit that immigrant minority youths’ embrace of native minority students’ cultural styles, including physical appearances and musical and linguistic styles, is positively associated 
with downward mobility. On the other hand, children of immigrants whose parents have higher levels of education; who live in more middle class, predominantly white neighborhoods; and who assimilate at the same rate as their parents, will experience upward assimilation. More recent formulations of segmented assimilation theory emphasize whether parents and children acculturate similarly or not (consonant or dissonant acculturation); again, this is determined by the receiving context, in addition to parents' human capital and the presence or absence of a local co-ethnic community (Portes, Fernández-Kelly, \& Haller, 2005; Portes \& Rumbaut, 2001).

\section{Empirical Critiques of Oppositional Peer Cultures}

Although Ogbu's theory of involuntary and voluntary minorities and Portes and his colleagues' theory of segmented assimilation theory dominate contemporary discussions of the links between culture and ethnic and racial stratification in education with respect to native and immigrant minority youth, some recent research calls the theories into question. The degree to which peer culture pressures African American and some second generation youth to avoid academic achievement has been hotly debated, in both qualitative and quantitative studies. In an investigation of the connections among achievement, popularity, and “acting white,” Fryer and Torelli (2005), using the National Longitudinal Study of Adolescent Health, found that in multiethnic schools high achievement among Black students leads to fewer same-race friends; however, they found that high achievement does not have a significant on the number of same-race friends in predominantly Black or private schools. On the other hand, Farkas and his colleagues (2002), using different survey data, found that high-achieving Black female 
students attending predominantly minority schools are more likely to be put down by peers. Datnow and Cooper (1997) interviewed forty-two African American high schoolers attending private schools in Baltimore and found no evidence of the stigma of “acting White”-in fact, they found that Black peers affirmed both Black identity as well as academic achievements. Analyses at the individual level can miss structural forces at work: Roscigno (1998) finds that when quantitative models take into account both macro and micro-level social processes, what appears in some studies as a peer aversion to academic achievement is actually due to tracking, segregation, and/or the school's climate.

Looking across groups also helps to analyze these social processes. For example, Lundy and Firebaugh (2005) find that peer approval cannot explain the behavior differences between African American and White or Asian students, discrediting the notion that a peer culture influences anti-school behaviors among Black students compared to Whites and Asians. They also find that the sanctions for high academic achievement are similar across race groups (see also Tyson \& Darity, 2005). Some have suggested that what is thought to be an anti-achievement peer culture among African American youth is actually a youth culture rooted in other aspects of cultureauthenticity, hip-hop consumption culture, and "black” ways of speaking (Carter, 2005; Jackson, 2001; Pattillo-McCoy, 1999).

In terms of attitudes, Black students have been found to have similar aspirations, expectations, and beliefs in the dominant achievement ideology to other race groups (Ainsworth-Darnell \& Downey, 1998; Carter, 2005; Cook \& Ludwig, 1998; Tyson \& Darity, 2005). Mickelson (1990) attempts to explain the "attitude-achievement paradox" 
of Black students' positive attitudes yet low achievement by distinguishing concrete and abstract attitudes. That is, she finds that Black students have positive abstract attitudes, yet concrete attitudes are more influenced by negative life experiences and observations of blocked opportunities for lower class Blacks. Ainsworth-Darnell and Downey (1998) critique Mickelson's study for failing to take into account the relationship between attitudes and achievement for all youth; the authors find that Black and White students have a similar relationship between attitudes and behaviors, so that that abstract attitudes do in fact matter for achievement and, consequently, they can't explain the black-white achievement gap.

Recent studies of children of immigrants have critiqued the use of oppositional culture explanations for the downward assimilation trajectory in segmented assimilation theory. Some of these arguments have shown that although some ethnic groups have lower educational and socioeconomic outcomes than the US average (e.g., second generation Mexicans and Dominicans), children of immigrants in those groups are still doing better than their parents (and than native comparison groups such as Puerto Ricans) in terms of academic attainment and income as adults (Kasinitz et al., 2008; Waldinger \& Feliciano, 2004). Furthermore, children of immigrants living in urban disadvantaged neighborhoods express positive attitudes toward academic achievement, and their taste preferences show no correlation between Black-identified styles (hip-hop and rap) and aspirations, perceptions of discrimination, or perceptions of oppositional cultures among their friends, as suggested by the oppositional culture explanations for downward assimilation (Warikoo, 2005). Others have suggested that because oppositional culture arguments include elements of youth cultures common to either all youth (Tyson \& 
Darity, 2005) or to all children of immigrants, including the previous wave (Perlmann \& Waldinger, 1997; Sassler, 2006), they cannot explain variation in academic achievement between ethnic groups. Similarly, Sue and Okazaki (1990) argue that Asian Americans, like other minorities, do anticipate limited mobility or limited access to the opportunity structure, like native minorities. However, they differ from other groups in that their limited access to attainment in non-educational arenas, such as leadership, politics, entertainment, and sports, leads them to overperform in school, their primary means for mobility. In terms of behaviors that negatively impact future life chances, Kasinitz and his colleagues (2008) show that although native whites and second generation young adults have similar experiences with being arrested, the consequences for arrest are graver for certain minority groups, which can lead them to worse academic outcomes. Given the oversights of the dominant theories of culture, race, and education, we next turn to how existing research can help to nuance these theories. Racial and ethnic identities emerge from the intersections of macro-structural, institutional (schooling), and individual-level forces; they are neither static nor one-dimensional, and their meanings, as expressed in schools, vary across time, space and region (Dolby, 2001; McCarthy, 1993; Yon, 2000).

\section{RACE, ETHNicity, AND THE CULTURAL ETHOS OF SCHOOLS}

Earlier perspectives on culture in education—namely, social and cultural reproduction—-theorized how schools reproduce class-based hierarchies through the reinforcement of dominant codes, artifacts, language, practices, interactions, and styles (Bernstein, 1971; Bourdieu \& Passeron, 1977). As Stanton-Salazar has argued: for 
socially marginalized racial and ethnic minority students, school success and attachment “has never been simply a matter of learning and competently performing technical skills; rather, and more fundamentally, it has been a matter of learning how to decode the system” (Stanton-Salazar, 1997: 13). The “system” comprises the school’s cultural environment, which engenders an allocation of resources, including prestige, social standing, and evaluations based on the degree to which students possess dominant cultural capital (Farkas, Grobe, Sheehan, \& Shuan, 1990). For those who have it, this capital provides advantages in how to negotiate the school's cultural environment, which is often based on a tacit understanding of middle-class ways of being and communicating, styles, and preferences (Bourdieu, 1986; Heath, 1983; Lareau, 2003; Lee, 2007; Lewis, 2003; Murrell Jr, 1994). Although minority groups have access to other forms of capital (Carter, 2003; Yosso, 2005), these non-dominant cultural capitals among youth generally do not gain school success like mainstream cultural capital does.

The school’s cultural environment also engenders assimilationist ideologies, which presuppose that the proper ends in education will have been achieved when minority groups can no longer be differentiated from the White majority in terms of education, economic status, or access to social institutions and their benefits; and when non-White students act, speak and behave as much as possible like the White middle class (Duncan, 2005; Rist, 1977; Sager \& Schofield, 1984). Often schools succumb to massive oversights in their curricula and pedagogy by erasing the different histories and social and economic realities of their students with only token nods to and discussions of difference (Banks, 2001; Delpit, 1997; Dempsey \& Noblit, 1993; Flores-González, 2002; Pollock, 2004; Valenzuela, 1999). Also, we know that connections exist between 
students' social locations (e.g., their race, class, and immigrant status), culture, and how they learn (see King, 2005; Lee, 2007; Nasir \& Hand, 2006). For example, Valenzuela (1999) found that Mexican American students in a large urban school in Houston experience "subtractive schooling” by the school denying their Mexican heritage and promoting assimilation to White America as the road to school success. School structures such as tracking, anti-Mexican culture, and an anti-Spanish bias in the curriculum made schooling a subtractive experience for Mexican American youth in Valenzuela's study. That is, particular policies of the school forced children to either assimilate and succeed or identify as Mexican American, be “silenced” and have their critiques of school ignored (Quiroz, 2001) and consequently disengage from school. Similarly, Flores-Gonzales (2002) describes the ways in which a Chicago school pushes Puerto Rican youth to either "street” or "school” identities; these identities in turn have implications for whether they drop out of high school.

Scholars in the tradition of critical race studies show how institutional racism is embedded in the organization and structure of schools and their "hidden curriculum" (Dixson \& Rousseau, 2005; Gillborn, 2006; Jay, 2003; Parker, Deyhle, \& Villenas, 1999; Solorzano \& Ornelas, 2004). These scholars have exposed supposedly "race-neutral” practices that disproportionately impact minority students adversely, such as the allocation of students to Advanced Placement and remedial classes (Solorzano \& Ornelas, 2004); lower level exams given to "low ability” students in Britain that predetermine a lack of high achievement (Gillborn, 2006); and schools' "hidden curricula” that are masked through seemingly inclusive multiculturalism policies (Jay, 2003). 
Other researchers have identified institutional structures of schooling that can have a positive impact on the academic achievement of minority students by fostering strong identities. Conchas (2006), in research at three schools in the same building in California, found that one school structure perpetuated the forced choice between achievement/assimilation and failure/ethno-racial identification that Ogbu suggests for involuntary minorities, while another did not. Conchas identifies school-level factors such as a cooperative versus competitive learning environments; and a small school with strong teacher-student relationships versus a large, anonymous school, that influence Latino youth being able to both achieve academically and also to maintain strong ethnic identities.

Similar to Conchas' findings in the schools with academically successful minority students, others have shown that a strong teacher-student culture fosters high achievement among African American youth. Ladson-Billings (1994) and Murrell (2000; 2002) show how teachers, through high-quality training and cultural sensitivity, produce strong achievement results from their minority students. Likewise, Gandara (2002) found that the Puente program in California, which promotes students' Latin American cultures and ethnic pride, and provides students with intensive mentoring leads to higher rates of college attendance. At the elementary school level, dual-language bilingual programs in which immigrant students and children of US-born parents learn in a half English and half immigrant-language environment provide immigrant students an environment where their cultures and especially home languages are valued and placed on par with English and the dominant culture; this in turn leads to higher academic achievement for English Language Learners (Torres-Guzman, 2007). 
Symbolic Meanings of Tracking

Culture also manifests through symbols, rules, and policies that help to shape the school's academic milieu. We know that practices such as ability grouping and tracking—frequently referred to as facilitators of resegregation within schools—affect students’ educational behaviors (Mickelson, 2001; Oakes, 1985; Roscigno, 1998; Tyson \& Darity, 2005). When Black students are disproportionately underrepresented in hightrack classes, peers outside of these classes are more likely to accuse their co-ethnic peers of “acting White;” but when Black students are proportionately represented across the tracks in schools, evidence of accusations of "acting White" to high achieving students is not found (Fryer \& Torelli, 2005; Mickelson, 2001; Tyson \& Darity, 2005). These findings suggest that an avoidance of "acting White" is an ethno-racial cultural phenomenon that shifts across school contexts. In other words, Black and Latino students' overrepresentation in lower-track classes in multiracial schools may lead to uninviting perceptions about the classes that would prepare them to fully realize their aspirations for college and professional lives beyond. Such educational practices may convey messages that interpret and symbolize particular tracks as the turf of one racial/ethnic group or another's. Furthermore, schools can either overtly or covertly reproduce racial meanings and inequality in their day-to-day activities, by mapping particular racial identities (i.e., Whiteness and Asian identity) onto knowledge and intelligence (Lewis, 2003). Thus, some Black and Latino students, especially, may come to view the AP, honors and advanced classes as the ones for Asian and White students, or the "smart kids" (Carter, 2005; Mickelson \& Velasco, 2006; Tyson \& Darity, 2005). The 
"regular" or general comprehensive courses, consequently, become known as the classes for the "less smart" kids. This may in turn lead to unintended consequences for Black and Latino student behaviors.

Lower-track classes (and schools serving predominantly poor and minority student bodies) are also known to be taught by less qualified and experienced teachers, affecting classroom behaviors and discipline (Darling-Hammond, 2004; National Commission on Teaching and America's Future, 1996). Chin and Phillips (2004) have found that middle school students frequently resist teacher authority in the classroom, and that it takes a skilled teacher who understands students' cultural worlds to overcome this "authority-thwarting.” Unfortunately, lower-track (and hence often Black and Latino) students are less likely to be engaged by skilled teachers. Meanwhile, some immigrant youth, such as various Asian immigrant groups, possibly benefit from the dominant "model minority" myth embraced by many, including teachers, as opposed to the narrative of academic inferiority generated about African Americans or Latinos (Osajima, 1988; Wong, Lai, \& Nagasawa, 1998).

Overall, the research sharply reveals the degrees to which school structures support different cultural identity models and reinforce social boundaries that influence ethno-racial differences in achievement outcomes. In spite of this research, when many researchers consider cultural factors they ignore the fact that schools are cultural actors, too, with pervasive ideologies, rules, and codes that bolster status hierarchies among social groups. As active social agents, students, in turn, adapt, respond, and reinforce the cultural lines of demarcation within schools. 
In this section, we assessed some of the existing literature on cultural influences of schooling with respect to school structure on racial and ethnic stratification in academic achievement. Some of this research emphasizes between-race differences. Other studies examine the variation within ethnic and racial groups, to expose the diversity of educational experiences among students grouped according to race and ethnicity. Such studies caution social scientists and researchers against conceptual and methodological reductionism, whereby the educational narratives that are constructed about particular social groups are based on differences in means and variances on testscore outcomes alone.

\section{IDENTITY FORMATION \& VARIATION WITHIN GROUPS}

According to O’Connor (2001), one sociological challenge in this millennium is a deeper understanding of the complex relationship between academic achievement, schooling behaviors and social identities. That is, how can we understand the intersections of racial or ethnic identities with other social identities (e.g., class, gender, sexuality, religion); acknowledge the contestations over their meanings as collective identities; be aware of their innumerable variants as individual identities; document the shifts in their collective meanings across time and space; and still keep them as a critical part of the equation of academic success or failure?

Much of educational research continues to speak of racial and ethnic groups as monolithic groups with particular patterns of behavior and characteristics, in spite of research showing internal diversity among them in many dimensions of the determinants of educational inequality. Sue and Okazaki (1990), as well as other researchers (Kao, 
1995; Kao \& Thompson, 2003; Ngo \& Lee, 2007), remind us that the pan-ethnic rubric of “immigrant” and the stereotype of the "model minority,” especially among Asian Americans, belies the material and educational realities of various ethnic Asian subgroups who do not fare as well as other Asian groups in school. These can be at the levels of community, schools, (immigrant) generation, diversity in individual forms of adaptation, and diversity of identities. In this section we identify research that demonstrates great heterogeneity within ethnic and racial groups in their identities and cultural practices at school.

As described earlier in this article, segmented assimilation theory acknowledges three types of assimilation: upward assimilation, downward assimilation, and selective acculturation, based in part on the community into which an immigrant family assimilates. Ethnic enclaves, according to some, can "shield” disadvantaged children of immigrants from the problems of the inner-city, but providing an ethnic network of support (Portes \& Bach, 1985; Portes \& Rumbaut, 2001; Portes \& Zhou, 1993; Zhou \& Bankston, 1998). Thus children of the same ethnic group will assimilate and identify according to the community context in which they live. Waters (1999) has mapped these forms of assimilation onto ethno-racial identities for Afro-Caribbean youth in New York, depending on their community contexts. Waters found that some children of AfroCaribbean immigrants maintained "immigrant” identities (this was, not surprisingly, mainly the immigrant generation); some identified racially as African American (predominantly those living in poor neighborhoods); and some identified ethnically so as to disidentify with African Americans (predominantly those living in more middle class, White areas, as with upward assimilation). These variable identities had implications for 
academic achievement: Waters suggests that African American identity led to low academic achievement while ethnic identities led to upward assimilation.

In the previous section, we discussed how at school culture can perpetuate stratification in academic achievement according to race and ethnicity. Also, researchers find that the shift from one schooling context to another-for example, going from being in the majority to the minority in a school—influences the meanings that students of the same ascribed background attach to their racial and ethnic identities (Ichiyama, McQuarrie, \& Ching, 1996). Several scholars find that students who share the "same" racial or ethnic position in the wider society have differential experiences from one schooling context to another (Conchas, 2001; Lewis, 2003; Willie, 2003). White students are not excluded from this pattern. For example, Perry (2002) found that White students in a predominantly White school felt free to don urban African American styles, unlike their White peers in multi-ethnic environments, who were much less likely to consume African American-rooted music and styles. Perry attributes this difference to the racially homogenous environment allowing the dissociation of style from the ethnic group from which it is rooted. That is, in the multi-ethnic environment, sporting styles associated with urban African American youth—baggy jeans, Timberland boots, a taste for hip-hop music, and more—-is associated with identification with African American students, unlike in the environment in which there are few African American students with whom to be associated.

In terms of diversity by generation, although most research on ethnic communities puts first, second, and beyond generations together (e.g., Portes \& Rumbaut, 2001; Purkayastha, 2005), research has shown that generations have distinct identities and 
adaptations to American society (Gans, 1992; Rumbaut, 2004; Waters, 1999). Marcelo and Carola Suárez-Orozco (1995) show evidence of academic differences between recently immigrated and second-generation Mexican students, explaining how these two groups differ in the degree of family influence on schooling behaviors and attitudes, and on approaches toward education. Further, some researchers have suggested that first generation optimism and positive outlooks from a "dual frame of reference” (SuárezOrozco \& Suárez-Orozco, 1995) attenuates dramatically in the second generation, sometimes leading to "second generation decline" or "downward assimilation" among the second generation (Gans, 1992; Portes \& Zhou, 1993). Some have further shown that the “1.5” generation (Park, 1999) —immigrants who arrive as children rather than as adults_and the "2.5 generation” (Ramakrishnan, 2004)—those with one immigrant and one USborn parent—and even “1.25” and “1.75” generations (Rumbaut, 2004) have distinct identities and characteristics.

Individuals adapt to their social environments in myriad ways. Ogbu, the earliest thinker to categorize ethno-racial groups dichotomously into "involuntary" and "voluntary" minorities, much later (in an article published posthumously in 2004) nuanced his argument by suggesting five possible responses of involuntary minorities to their disadvantaged situation, only one of which is oppositional: assimilation, accommodation without assimilation, ambivalence, opposition, and encapsulation (complete segregation). Carter (2005) similarly identifies three kinds of identities among young Black and Latino residents in Yonkers, NY low-income housing complexes: noncompliant believers, cultural mainstreamers, and cultural straddlers. Carter's research shows the complexity of minority youth's adaptations to the cultural worlds of their schools and peer groups, even among 
youth living in the same community. Noncompliant believers, although they most likely "believe in education," chafe under the culture of the schools-restrictions on clothing, speech, and teachers' perceptions and evaluations of students based on visual cues—and as a result, often conflict with school authorities. Their academic profiles range from average to failing students. Cultural mainstreamers are focused on success in the greater society; they prefer to emulate those whom they observe in power. For them, "acting White" is not the cause of their school success, although they believe that these cultural cues are the signals of intelligence and professional success. Cultural straddlers are able to operate in both White culture and their own, fluently switching between the slang, dress, tastes, and styles of their culturally similar friends and the Standard English and codes of the dominant culture.

Ethnographic studies of youth demonstrate different types of engagement with delinquent behaviors within ethno-racial groups. Pattillo-McCoy (1999) describes the differential ways in which African American youth of all socio-economic backgrounds engage with "ghetto culture": some are consumed by ghetto culture; some are thrilled by ghetto culture; and some are marginal to ghetto culture. Pattillo-McCoy argues that consumed individuals are the only ones engaging in serious delinquent and oppositional behaviors, even if those who are thrilled exhibit the stylistic accoutrements of ghetto culture. In research on street culture in Philadelphia’s poorest neighborhoods, Anderson (1999) contrasts street with decent youth by their orientations toward conflict and illegal behaviors in inner city Philadelphia. In terms of attitudes, Ann Ferguson (2000) contrasts “Troublemakers”, who disidentify with school, with "Schoolboys” who have a more positive orientation toward schooling. 
Similar to the above studies of African American and Latino youth, research on Asian Americans has also documented diverse adaptations to dominant school cultures. Challenging the "model minority" stereotype about their academic achievement, Lee (1996) discusses how Asian American students at a high-achieving east coast public high school are not a monolithic group and are quite diverse in terms of their identities within the school culture (see also Ngo \& Lee, 2007). Lee exposes how powerful educational gatekeepers perpetuate certain ethnic narratives by showing how teachers at Academic High (a pseudonym) persisted in characterizing all Asians as highly motivated and successful when in reality some were not. In spite of these narratives, Lee discovered that Asian students separated themselves into four groups: Korean, Asian-identified, Asian New Wave, and Asian American. Students identified with these groups variably, depending on their social class backgrounds, academic achievement, parents' nationality, political orientation, and more.

Lastly, individuals do not always identify as the groups into which social scientists name and categorize them. For example, Kasinitz and his colleagues (Kasinitz et al., 2008) in the Second Generation in Metropolitan New York study found that young adult study respondents often did not identify with the categories they assumed. In their study of eight ethnic and racial groups in New York City, they found that individuals gave twenty-seven different answers to the US Census race questions, and one hundred different answers to the US Census ancestry questions, leading researchers to conclude that the official race categories are not useful in describing how individuals see themselves (Kasinitz et al., 2008: page 68). In addition, how individuals identify is contextual: Harris and Sim (2002) found that $12 \%$ of youth participating in the National 
Longitudinal Study of Adolescent Health survey gave different answers to questions on race and ethnicity depending on whether they were asked the questions at home or at school.

In a different strand of literature, researchers who acknowledge diverse modes of adaptation have attempted to identify which type of racial and ethnic identitiesassimilative, bicultural, or resistant—lead to high academic achievement. However, the findings are mixed. On one end of the spectrum, Fordham (1988) shows that highachieving Black students embrace a "raceless” persona as a strategy to navigate various schooling avenues to avoid being accused of "acting White” by co-ethnics. On the other hand, social psychologists show that a strong ethnic identity is linked to relatively higher academic achievement (Bowman \& Howard, 1985). Oyserman and her colleagues (2007) complicate these explanations for how racial and ethnic identities impact academic achievement. They show that the degree to which ethnic and racial identities help African American and Latino youth cope with the challenges of racial stratification and discrimination determines their impact on academic outcomes. They suggest that not only feelings of "connectedness" to the identity group and "awareness of racism" but also "embedded achievement”- - beliefs that achievement is a goal that is valued by the ingroup and therefore provides a specific goal (such as doing well in school) for motivation derived from the desire to enact group identity,” (page 98)—will lead to higher academic achievement. Sellers, Chavous and Cooke (1998) find that among those students who maintain a salient and central racial identity, those who hold a "minority" ideology or beliefs of themselves as members of one of several subordinated groups in U.S. society 
have significantly higher grade point averages than those with assimilationist or nationalist ideologies. ${ }^{5}$

Oyserman and her colleagues (2007) suggest that minority youth with "dual racialethnic self-schema" are best poised to do well in school. Other research also shows that students who cling to a strong ethnic or racial identity and also subscribe to various practices of dominant society fare better in school than both "raceless" individuals and those with more racial and ethnic nationalist orientations. For example, Deyhle (1995) found that the more successful Navajo students tend to be those who are dually culturally competent or bicultural. Navajo youth who are better integrated into their home cultures and also somewhat adapted to the mainstream will be most successful, regardless of the structural barriers. Deyhle’s argument is consistent with Gibson’s (1988) accommodation without assimilation thesis, as well as Mehan and his colleagues' research (1994) showing how academically successful native racial and ethnic minority students navigate between two worlds: dominant culture (i.e., White middle-class) and home culture.

In terms of psychological measures, research in social psychology suggests that for disadvantaged groups, learning about ethnic or race culture can bolster self-esteem, and, more generally, a strong ethnic identity mixed with a mainstream orientation leads to higher self-esteem (Phinney, 1991). There are thinkers who challenge bi- and multicultural identity models, however, especially when they promote racial minority youth's adherence to "White" cultural norms and do not encompass a critique of extant social and cultural inequality (see Duncan, 2005). That is, mainstream beliefs about "respectability” 
lead to expectations that minority youth conform to dominant culture and forgo minority cultural ways of being (Duncan, 2005).

In this section we have demonstrated the great variability that research has shown within ethnic and racial groups and their social and cultural identities and adaptations. Another dimension of variability within ethnic and racial groups is the different aspects of cultural practices within individuals. That is to say, culture includes multiple components—consumption, attitudes, worldviews, and behavioral scripts (Griswold, 1994), all of which may or may not correspond in ways that are obvious or expected. In the next section we present the literature on the various dimensions of culture and their influence on myriad schooling and educational behaviors among racial and ethnic minorities.

\section{Multiple Dimensions of CUlture}

A common assumption by much of the literature on race, ethnicity, and education is that the dimensions of culture—values, expressions, consumption patterns, and shared identities—have a standard relationship, which is often not the case. Often these assumptions are made in the equation of certain patterns of expressive culture-styles of dressing, walking, and speaking - to negative orientations toward dominant society, and toward schooling in particular (Carter, 2003; Jackson, 2001; Pattillo-McCoy, 1999; Warikoo, 2005). Foner (2005) aptly describes this as "confusing style for substance” (page 58). In fact, even if cultural practices, tastes, and preferences differ, myriad social groups share societal norms, which define "right" and "wrong" or "good" and "bad" (Gould, 1999; Merton, 1968). Socialized in a world that exhibits how educational 
credentials are linked to economic success, few ethno-racial groups are found to disparage education's intrinsic value. Scholars have too often ignored the very real tensions between 1) the symbolic cultural boundaries set by various groups of studentswhich often have little to do with their taste for achievement and success and 2) those cultural markers used by school officials to evaluate intelligence and competence. Ethnographic research has shown that students can exhibit styles associated with disadvantaged groups and maintain high aspirations and positive outlooks. For example, Jackson (2001) gives a nuanced description of behaviors among youth in Harlem, suggesting that particular behaviors are necessary to demonstrate Black racial authenticity, but those behaviors are not opposed to academic achievement: Being called "White" or being accused of "acting White" is not simply anti-intellectualism. It is more about the microbehaviors in the school building (how one walks down the hall, sits at the desk, stands on line, talks to one's classmate) that spark the invocation of Whiteness as a potential critique of racial identity. One's score on a multiple-choice math test in third period doesn't signify Whiteness. It is not performing intellectualism that is the problem, but rather the other performances of self that are often seen as correlated with (but not identical to) intellect (p. 186).

That is to say, academic achievement does not factor into perceptions of Black (or White) racial identity. Jackson illustrates this point by describing a 17-year old Black boy in Harlem who wears baggy jeans and a tilted hat, and speaks using African American 
slang. The boy earns straight A's, and when asked about whether his grades affect his image, he says simply that "girls like it”(Jackson, 2001).

Among other groups, our research in the United States, Britain, and South Africa show that the peer consumption culture associated with Black youth is similar to their non-Black peers as well (Carter, 2008; Warikoo, 2005; see also Dolby, 2001). The cultural diffusion of hip-hop music and style, as produced by African American and Latino youth, spans the globe. Warikoo (2005) finds that second generation Indians in both London and New York inhabit similar cultural worlds—-heavily influenced by the U.S. hip-hop scene — to their native White and second generation Afro-Caribbean peers in the same schools, in terms of expressive styles and consumption. Paradoxically, the consumption of hip-hop (read as "black culture") does not imply an identification with or acceptance of African Americans. As Maira’s (2002) research among young South Asians in New York suggests, the consumption of black popular culture can coexist with entrenched negative stereotypes and disrespect for Black people. In short, the connections among race, ethnicity, culture, and achievement are complex and prone to some troublesome conflations.

\section{THE INTERSECTIONS OF SOCIAL IDENTITIES: RACE, ETHNicity, Class, AND GENDER}

In 1964 Milton Gordon published his classic study of immigrant incorporation, Assimilation in American Life (1964), still read by students of immigration today. In the book Gordon develops the concept of “ethclass” groups, which he defines as class groups within ethnic groups. Ethclass, according to Gordon, is the best unit of analysis for understanding the participation of minorities in US society, rather than simply ethnicity, 
which has a more historical connotation, emphasizing country of origin rather than position in US society. Gordon's analysis highlighted the importance of understanding the intersections of identities within individuals, rather than analyzing social divisions such as class, race, and gender separately. Although Gordon pointed to the importance of studying the intersection of race and class, much of current research on race, ethnicity, culture, and achievement relies on an additive, causal model rather an intersectional model that exposes the complex and variable outcomes within different racial and ethnic groups in terms of overlapping identities (see also Collins, 1991).

Research that simply adds different variables of identity (for example, race, class, gender) misses the ways in which these social identities intersect, often in unexpected ways. For example, previous research suggests how the intersections of race and class render differential academic expectations between groups_-MacLeod's (1995) “Hallway Hangers" (mostly White) versus the "Brothers” (mostly Black), or rather why poor and working-class White males might aspire towards working class jobs, while poor and working class Black males show tastes for White-collar jobs. Furthermore, the intersections of race, ethnic, and class position necessitate more expansive understandings of how identities function, since poor and working-class students, in general, do not excel as much as their middle-class counterparts (Heath \& McLaughlin, 1993). Researchers provide varied reasons for these within-ethnic and within-race and class differences. Some attribute them to differential social and material resources (Louie, 2001; Stanton-Salazar, 2001), or to teacher-student social class mismatch (Alexander, Entwisle, \& Thompson, 1987; Dance, 2002; Farkas et al., 1990; Ferguson, 1998). 
Recent research discusses the ways in which high achieving and middle class minority students cope with racial disadvantage and class advantage. For example, Neckerman and her colleagues (1999) have documented a minority culture of mobility that supports middle class minorities. Horvat and Lewis (2003) have documented the ways in which high-achieving Black girls in school manage their academic success by “camouflaging” among low-achieving Black peers, while gaining support among highachieving Black peers. Douglas Foley $(1988,1990)$ has shown how middle class Mexican American students in Texas use class advantage and "impression management" (Goffman, 1971) to improve their academic achievement.

Class differences lead Asian Americans to different trajectories. Louie (2004) has documented how some working class Chinese American students (especially those at a relatively less prestigious college) see themselves as contradicting the Asian American “model minority” stereotype. Their self-understandings are shaped by class and others' assumptions about the supposed success of Asian Americans. Espiritu’s (1994) research on the children of professional Filipino immigrants shows how class privilege combined with minority racial status can lead to ethnic identities that are simultaneously "symbolic" (Gans, 1979), demonstrating assimilation into mainstream America, and also critical of racial discrimination in American society.

In addition to the recent work on the intersection of race and class, there exists a growing body of literature that analyzes the intersection between gender and race/ethnicity with respect to educational achievement and culture. Girls are now known to outperform boys academically (Coley, 2001; Donahue et al., 1999; Knapp, 2005; Massey, Charles, Lundy, \& Fischer, 2003), in spite of some continued gender inequality 
in the classroom in favor of boys (American Association of University Women Educational Foundation, 1992). Using data from San Diego of the Children of Immigrants Longitudinal Study, Feliciano and Rumbaut (2005) found that middle school female children of immigrants had higher occupational aspirations than did their male counterparts, and girls were more likely to attain their occupational aspirations-this was true even for those aspiring to traditionally male occupations.

In terms of ethnic identity, second generation girls are more likely to adopt bicultural identities than are second generation boys; these are thought to lead them to higher academic achievement outcomes (Carter, 2005; López, 2002; Waters, 1996). For example, Nancy Lopez, in a study of young Dominican New Yorkers (2002), found that girls were able to simultaneously maintain a critique of the negative aspects of their schools while still achieving academically; boys in Lopez's study had a harder time with this balance and hence were at greater risk of dropping out of school. Lopez describes "race-gender experiences" and "race-gender stigma", highlighting the complex interaction between race and gender in the lives of the young Dominicans in her study. Carter (2005) similarly takes a race and gender intersectional approach and finds that female minority students are more likely to become cultural straddlers (and cultural mainstreamers), while male students, in an attempt to become "hard" and "street," may be more likely to see their schooling end up in the noncompliant believer category. In addition, Carter shows how young African American and Latino boys and girls in her study struggled to maintain their masculine and feminine selves, respectively; these "hard" and "soft" images have implications for school performance as well as for future job prospects in a service economy, where institutional gatekeepers feel threatened by "hard" images coming from minority men. 
Research has shown that minority boys and girls also face different forms of racialization in school, and further school authorities are quicker to see minority boys as dangerous and defiant compared to their female and white male counterparts (Ferguson, 2000; López, 2002). It is suggested that a strong sense of racial in-group membership may improve the academic engagement of minority boys, possibly as a buffer against discrimination (Oyserman, Brickman, Bybee, \& Celious, 2006). A simple additive model of combining racial stigma with gender stigma could not have uncovered the complexity of the intersection of these identities, which lead girls to less cultural conflict with the dominant culture of their schools and consequently higher academic achievement than boys. In addition to experiences of race-gender stigma, minority boys and girls have different expectations in the family—immigrant parents are often more strict with girls, while boys are allowed to go out more and interact with friends outside the home more than their sisters; this differential family treatment sometimes leads girls to higher academic achievement than their brothers, as well (Bankston, 1995; Gibson, 1988; Horowitz, 1983; López, 2002).

\section{Towards a New Direction: Culture, RaCE, ETHNicity AND ACHIEVEMENT}

In this article we have unpacked the complexity of the relationship between culture and academic achievement among ethnic and racial groups. Indeed cultural ecological theory, as conceived originally by John Ogbu in the 1970s, integrated structural, institutional, cultural, and social psychological components to explain academic and economic mobility. And, in a more recent formulation of segmented assimilation theory Portes and his colleagues have emphasized the great importance of structures, possibly 
outweighing the cultural influences on trajectories of assimilation (Portes, FernándezKelly, \& Haller, 2005, pages 1031-1032). Yet, as the concept of oppositional culturethe component of these theories discussed most widely within educational researchbegan to monopolize researchers' attention, the wider framework was lost. That is, many researchers have allowed the idea of peer culture's negative influence to supplant the roles of other social factors. Moreover, the lack of clarity among scholars on dimensions of culture manifests itself also in the dominant framing of ethno-racial cultures for different groups. As this literature shows, arguments based merely on peer oppositional cultures cannot predominate the share of cultural explanations for why racial and ethnic disparities in academic achievement and engagement exist.

We propose that as researchers seek to understand the complex and dynamic relationship between ethno-racial identities, culture and achievement, they must interrogate race and ethnicity not only as determinants of educational outcomes but also as the product of myriad social processes themselves. That is, race and ethnic identity formation not only constitute one of several antecedent factors in models theorizing and predicting achievement and mobility patterns, but also these identity formations are dependent on a number of other personal and contextual factors. Thus, in order to explain stratification, studies should not merely highlight racial and ethnic differences by examining race and ethnicity as simple independent variables as many studies conventionally do. Most scholars of race and ethnicity no longer see them as primordial, but rather constructed out of various social processes and historical circumstances—what Omi and Winant (1994) refer to as "racial formations.” And new studies should 
incorporate an understanding of the processes of racialization if they seek to attribute social and academic outcomes to race.

In addition, research that incorporates cultural arguments to explain differential outcomes between immigrant and native minority youths should be designed to unpack the dimensions of culture that supposedly lead to the differential outcomes. Much diversity exists within ethnic groups in terms of cultural identities, and further, culture in itself is multifaceted. Social scientists should differentiate between normative ideologies and subjective cultural practices—components that mark and shape group identity. There is not a neat or standard way in which the multiple aspects of culture fit together, and individuals participate in multiple cultural spheres—ethnic cultures, youth cultures, gender cultures, and class cultures, to name a few.

Methodologically, much of the research on race, ethnicity, and education, focuses on one ethnic or racial group, often through in-depth qualitative research; then, it draws conclusions about that group, rather than questioning whether the behaviors observed are endemic to the group or a part of a larger social phenomenon. Such studies benefit from a close focus on a particular group; however, the disadvantage with these studies is the lack of discussion of the degree to which the social processes described are particular to the group studied, or instead are also a product of class, age, or another variable the group shares with other groups not studied (see also Wimmer, 2007). For example, although rap music has been associated with delinquency and oppositional cultures (Ferguson, 2001; McWhorter, 2001; Zhou \& Bankston, 1998), many—if not most—White teens in suburban schools also have strong preferences for hip-hop and rap music (Perry, 2002), as evidenced by academic studies as well as the top 40 songs. Quantitative studies have 
found similar attitudes toward education and aspirations among Black and White students, thus negating explanations of Black underachievement that argue that Black students undervalue academic achievement (Ainsworth-Darnell \& Downey, 1998; Cook \& Ludwig, 1998). In fact it is the teen subculture of rock, punk, and goth music and styles that defines itself consciously as rebellious and anti-authority; however, perhaps because participants in this subculture are predominantly White, the subculture is not portrayed in the literature as a deviant subculture that leads some youth to poor outcomes. ${ }^{6}$ It is no surprise that the Black-identified subculture is discussed quite differently, given how racial dynamics and forces operate in U.S. society; yet the interpretation of Blackidentified subculture and its link to achievement is problematic.

Yet, the problem is not simply one of qualitative versus quantitative research. Many large-scale survey studies fail to amply investigate the more complex interactions among multiple identities, and instead take additive approaches. Despite the growing research demonstrating variability within the traditional boundaries of Asian Americans, Hispanic Americans, and African Americans, many researchers continue to use these categories to explain outcomes. In our own research, the qualitative comparative study of peer cultures allows us to understand the ways in which it is and is not linked to educational behaviors, both among low achieving groups and high achieving groups, and across ethnic and racial groups (Carter, 2005; Carter, 2008; Warikoo, 2005). Furthermore, looking comparatively across race groups and across national contexts allows us to distill what is unique to specific ethno-racial groups and to national contexts.

In suggesting cultural explanations for ethnic stratification in academic achievement, we argue that scholars and researchers should first outline which aspects of 
culture matter; when and how those cultures are linked to ethnicity/race; and when that ethno-racial cultural identity is activated for students. To a large degree, qualitative researchers have uncovered the rather nuanced and complex intersections between racial, ethnic, and cultural identities and provided us with more insight about how and why these identities matter. Still, the generalizability of these conclusions can only follow from more intensive and wide-scale studies of racial and ethnic identities in schools.

Paradoxically, students cannot be neatly categorized into any one or more racial and ethnic identities, especially since individuals contest one another over what it means to belong to a particular racial or ethnic group in this global and postmodern era (Tuan, 1999; Yon, 2000). Furthermore, students are embedded in a web of social identities; thus, it is simply dangerous to attribute schooling behaviors to a singular racial, ethnic or cultural identity. As O’Connor (2001: 166) argues: “consistent with the logic of metaanalysis, which operates in relation to quantitative studies, sociologists need to develop narratives that theoretically integrate the findings of [the] microanalyses of why children perform the way they do in America's schools.” The challenge is to cultivate more multitiered theoretical approaches to racial and ethnic identities, culture, and schooling, so that we can fully capture their temporal, contextual, and dynamic dimensions and effects.

\section{Note}

The authors wish to thank Michal Kurlaender and the reviewers and editors of $R E R$ for their suggestions and feedback. Please direct all correspondence concerning to either Prudence L. Carter (plcarter@stanford.edu) or Natasha Warikoo (Natasha.Warikoo@sas.ac.uk). 


\section{REFERENCES}

Ainsworth-Darnell, J. W., \& Downey, D. B. (1998). Assessing the Oppositional Culture Explanation for Racial/Ethnic Differences in School Performance. American Sociological Review 63(4), 536-554.

Alexander, K. L., Entwisle, D. R., \& Thompson, M. S. (1987). School Performance, Status Relations, and the Structure of Sentiment: Bringing the Teacher Back In. American Sociological Review, 52(5), 665-682.

American Association of University Women Educational Foundation. (1992). How Schools Shortchange Girls.

Anderson, E. (1999). Code of the street : decency, violence, and the moral life of the inner city (1st ed.). New York: W.W Norton.

Appiah, K. A. (1996). Race, Culture, Identity: Misunderstood Connections. In K. A. Appiah \& A. Gutmann (Eds.), Color Conscious: The Political Morality of Race. Princeton, NY: Princeton University.

Banks, J. A. (2001). Multicultural Education: Characteristics and Goals. In J. Banks \& C. McGee Banks (Eds.), Multicultural Education: Issues and Perspectives (4th Edition ed., pp. 3-30). New York: John Wiley and Sons.

Bankston, C. L. (1995). Gender roles and scholastic performance among adolescent Vietnamese women: the paradox of ethnic patriarchy. Sociological Focus, 28(2), 161-176.

Bernstein, B. (1971). Class, Codes, and Control. London: Routledge \& Kegan Paul.

Blau, P. M., \& Duncan, O. D. (1967). The American Occupational Structure. New York: Wiley.

Bourdieu, P. (1986). The Forms of Capital. In J. G. Richardson (Ed.), Handbook of Theory and Research for the Sociology of Education New York: Greenwood Press.

Bourdieu, P., \& Passeron, J. C. (1977). Reproduction in Education, Society and Culture. Beverly Hills: Sage.

Bowles, S., \& Gintis, H. (1976). Schooling in Capitalist America: Educational Reform and the Contradictions of Economic Life. New York: Basic Books.

Bowman, P., \& Howard, C. (1985). Race-related Socialization, Motivation, and Academic Achievement: A study of Black Youth in Three-Generation Families. Journal of the American Academy of Child Psychiatry, 27, 134-141.

Brubaker, R., \& Cooper, F. (2000). Beyond 'identity'. Theory and Society, 29(1), 1-47.

Caplan, N., Choy, M., \& Whitmore, J. (1991). Children of the Boat People: A Study of Educational Success. Ann Arbor: University of Michigan Press.

Carter, P. (2003). 'Black' Cultural Capital, Status Positioning, and Schooling Conflicts. Social Problems 50(1), 136-155.

Carter, P. (2005). Keepin' it real : school success beyond black and white. New York: Oxford University Press.

Carter, P. L. (2008). Racial Desegregation and the Multiple Dimensions of Boundaries in South African Schools.Unpublished manuscript, Palo Alto, CA.

Chin, T., \& Phillips, M. (2004). Oppositional to What? Achievement Ideologies, Resistance, and Ethnic Authenticity among Urban Youth, Paper presented at the Annual Meeting of the American Sociological Association. San Francisco, CA. 
Coley, R. J. (2001). Differences in the Gender Gap: Comparisons Across Racial/Ethnic Groups in Education and Work: Educational Testing Service, Policy Information Center Report.

Collins, P. H. (1991). Black Feminist Thought. New York: Routledge.

Conchas, G. (2006). The Color of Success: Race and High-Achieving Urban Youth. New York: Teachers College Press.

Conchas, G. Q. (2001). Structuring Failure and Success: Understanding the Variability in Latino School Engagement. Harvard Educational Review, 71(4), 475-504.

Cook, P. J., \& Ludwig, J. (1998). The Burden of 'Acting White': Do Black Adolescents Disparage Academic Achievement? In C. Jencks \& M. Phillips (Eds.), The BlackWhite Test Score Gap (pp. 375-393). Washington, D.C.: Brookings Institution Press.

Cornell, S. (1994). Ethnicity as Narrative: Identity Construction, Pan-Ethnicity, and American Indian Supratribalism. Paper presented at the Annual Meeting of the American Sociological Association, Los Angeles , CA.

Dance, L. J. (2002). Tough Fronts: The Impact of Street Culture on Schooling. New York: Routledge.

Darling-Hammond, L. (2004). Inequality and the Right to Learn: Access to Qualified Teachers in California's Public Schools. Teachers College Record, 106(10), 19361966.

Datnow, A., \& Cooper, R. (1997). Peer networks of African American students in independent schools: Affirming academic success and. Journal of Negro Education, 66(1), 56.

Davies, S. (1995). Reproduction and Resistance in canadian High schools: An Empirical Examination of the Willis Thesis. The British Journal of Sociology, 46(4), 662687.

Dawkins, M. P., \& Braddock Ii, J. H. (1994). The continuing significance of desegregation: School racial composition and African American. Journal of Negro Education, 63(3), 394.

Delpit, L. (1997). The Silenced Dialogue: Power and Pedagogy in Educating Other People's Children. In A. H. Halsey \& H. Lauder \& P. Brown \& A. S. Wells (Eds.), Education: Culture, Economy and Society (pp. 582-594). New York: Oxford University Press.

Dempsey, V., \& Noblit, G. W. (1993). Cultural Ignorance and School Desegregation: Reconstructing a Silenced Narrative. Educational Policy, 7(3), 318-330.

Deyhle, D. (1995). Navajo Youth and Anglo Racism: Cultural Integrity and Resistance. Harvard Educational Review, 65(3), 403-444.

Dixson, A. D., \& Rousseau, C. K. (2005). Editorial. Race, Ethnicity \& Education, pp. 15.

Dolby, N. (2001). Constructing Race: Youth, Identity, and Popular Culture in South Africa. Albany: State University of New York.

Donahue, P. L., Voelkl, K. E., Campbell, J. R., \& Mazzeo, J. (1999). NAEP 1998 Reading Report Card for the Nation and the States: National Center for Education Statistics, Office of Educational Research and Improvement, US Department of Education. 
Duncan, G. A. (2005). Black Youth, Identity, and Ethics. Educational Theory, 55(1), 322.

Espiritu, Y. L. (1994). The Intersection of Race, Ethnicity, and Class: The Multiple Identities of Second-Generation Filipinos. Identities, 1(2-3), 249-273.

Farkas, G., Grobe, R. P., Sheehan, D., \& Shuan, Y. (1990). Cultural Resources and School Success: Gender, Ethnicity, and Poverty Groups Within An Urban School District. American Sociological Review, 55, 127-142.

Farkas, G., Lleras, C., \& Maczuga, S. (2002). Does Oppositional Culture Exist in Minority and Poverty Peer Groups? American Sociological Review, 67(1), 148155.

Feliciano, C., \& Rumbaut, R. n. G. (2005). Gendered paths: Educational and occupational expectations and outcomes among adult children of immigrants. Ethnic \& Racial Studies, 28(6), 1087-1118.

Ferguson, A. A. (2000). Bad boys : public schools in the making of Black masculinity. Ann Arbor: University of Michigan Press.

Ferguson, R. (1998). Can schools narrow the black-white test score gap? In C. Jencks \& M. Phillips (Eds.), The black-white test score gap (pp. 318-374). Washington, D.C.: Brookings Institution Press.

Ferguson, R. (2001). Test-Score Trends Along Racial Lines, 1971-1996: Popular Culture and Community Academic Standards. In N. J. Smelser \& W. J. Wilson \& F. Mitchell (Eds.), America Becoming: Racial Trends and Their Consequences, Volume 1 (pp. 348-390). Washington, DC: National Academy Press.

Flores-González, N. (2002). School kids/street kids : identity development in Latino students. New York: Teachers College Press.

Foley, D. E. (1988). From peones to politicos : class and ethnicity in a South Texas town, 1900-1987 (Rev. and enl. ed.). Austin: University of Texas Press.

Foley, D. E. (1990). Learning capitalist culture : deep in the heart of Tejas. Philadelphia: University of Pennsylvania Press.

Foner, N. (2005). In a new land : a comparative view of immigration. New York: New York University Press.

Fordham, S. (1988). Racelessness as a Factor in Black Students' School Success: Pragmatic Strategy or Pyrrhic Victory? Harvard Educational Review, 58(1), 5484.

Fordham, S. (1996). Blacked out : dilemmas of race, identity, and success at Capital High. Chicago: University of Chicago Press.

Fordham, S., \& Ogbu, J. (1986). Black Students' School Success: Coping with the 'Burden of Acting White'. Urban Review, 18, 176-206.

Fryer, R. G., \& Torelli, P. (2005). An Empirical Analysis of 'Acting White'. Cambridge, MA: National Bureau of Economic Research, Working Paper Series, Working Paper 11334.

GÃ ndara, P. (2002). A Study of High School Puente: What We Have Learned About Preparing Latino Youth for Postsecondary Education. Educational Policy, 16(4), 474.

Gaines, D. (1991). Teenage wasteland : suburbia's dead end kids (1st ed.). New York: Pantheon Books. 
Gans, H. J. (1979). Symbolic Ethnicity: The Future of Ethnic Groups and Cultures in America. Ethnic and Racial Studies, 2(1).

Gans, H. J. (1992). Second-generation decline: Scenarios for the economic and ethnic futures of the post--1965 American immigrants. Ethnic \& Racial Studies, 15(2), 173.

Gibson, M. A. (1988). Accomodation without Assimilation: Sikh immigrants in an American high school. Ithaca: Cornell University.

Gillborn, D. (2006). Rethinking white supremacy. Ethnicities, 6(3), 318.

Giroux, H. (1983). Theory and Resistance in Education: A Pedagogy for the Opposition. London: Heinemann Education Books.

Goffman, E. (1971). The presentation of self in everyday life. Harmondsworth: Penguin.

Gordon, M. M. (1964). Assimilation in American life: the role of race, religion, and national origins. New York,: Oxford University Press.

Gould, M. (1999). Race and Theory: Culture, Poverty and Adaptation to Discrimination in Wilson and Ogbu. Sociological Theory, 17(2), 171-200.

Griswold, W. (1994). Cultures and societies in a changing world. Thousand Oaks London: Pine Forge Press.

Hall, S., \& Jefferson, T. (1976). Resistance through rituals : youth subcultures in postwar Britain. London: Hutchinson.

Harris, D. R., \& Sim, J. J. (2002). Who is Multiracial? Assessing the Complexity of Lived Race. American Sociological Review, 67(4), 614-627.

Heath, S. B. (1983). Ways with words : language, life, and work in communities and classrooms. Cambridge [Cambridgeshire] ; New York: Cambridge University Press.

Heath, S. B., \& McLaughlin, M. W. (1993). Identity and Inner-city Youth : Beyond Ethnicity and Gender. New York: Teachers College Press.

Hebdige, D. (1979). Subculture : the meaning of style. London ; New York: Routledge.

Hollinger, D. A. (1995). Postethnic America : beyond multiculturalism. New York: BasicBooks.

Horowitz, R. (1983). Honor and the American dream : culture and identity in a Chicano community. New Brunswick, N.J.: Rutgers University Press.

Horvat, E. M., \& Lewis, K. S. (2003). Reassessing the "Burden of 'Acting White"': The Importance of Peer Groups in Managing Academic Success. Sociology of Education, 76(4), 265-280.

Ichiyama, M. A., McQuarrie, E. F., \& Ching, K. L. (1996). Contextual influences on Ethnic Identity among Hawaiian Students in the Mainland United States. Journal of Cross-Cultural Psychology, 27(4), 458-475.

Jackson, J. (2001). Harlemworld: Doing Race and Class in Contemporary Black America. Chicago: University of Chicago Press.

Jay, M. (2003). Critical Race Theory, Multicultural Education, and the Hidden Curriculum of Hegemony. Multicultural Perspectives, 5(4), 3-9.

Jencks, C., \& Phillips, M. (1998). The black-white test score gap. Washington, D.C.: Brookings Institution Press.

Kao, G. (1995). Asian Americans As Model Minorities? A Look at Their Academic Performance. American Journal of Education, 103(121-159). 
Kao, G., \& Thompson, J. S. (2003). Racial and Ethnic Stratification in Educational Achievement and Attainment. Annual Review of Sociology, 29, 417-442.

Kasinitz, P., Mollenkopf, J. H., Waters, M. C., \& Holdaway, J. (2008). Inheriting the City: The Children of Immigrants Come of Age. Cambridge: Harvard University Press.

Keesing, R. M. (1974). Theories of Culture. Annual Review of Anthropology, 3, 73-97.

King, J. E. (Ed.). (2005). Black Education: A Transformative Research and Action Agenda for the New Century. Mahwah, NJ: Lawrence Erlbaum Associates.

Knapp, L. G. (2005). Postsecondary Institutions in the United States: Fall 2003 and Degrees and Other Awards Conferred: 2002-2003: US Department of Education, Institute of Education Sciences, NCES 2005-154.

Ladson-Billings. (2006). From the Achievement Gap to the Education Debt: Understanding Achievement in U.S. Schools. Educational Researcher, 35(7), 312.

Lamont, M., \& Molnár, V. (2002). The Study of Boundaries in the Social Sciences. Annual Review of Sociology, 28(167-95).

Lareau, A. (2003). Unequal Childhoods: Class, Race, and Family Life. Berkeley, CA: University of California Press.

Lee, C. D. (2005). The State of Knowledge about the Education of African Americans. In J. E. King (Ed.), Black Education: A Transformative Research and Action Agenda for the New Century (pp. 45-72). Mahwah, NJ: Lawrence Erlbaum Associates.

Lee, C. D. (2007). Culture, Literacy, and Learning: Taking Bloom in the Midst of the Whirlwind. New York: Teachers College Press.

Lee, S. J. (1996). Unraveling the "Model Minority" Stereotype: Listening to Asian American youth. New York: Teachers College Press.

Lewis, A. E. (2003). Race in the Schoolyard: Reproducing the Color Line in School. New Brunswick, NJ: Rutgers University Press.

Lewis, O. (1969). The Culture of Poverty. In D. P. Moynihan (Ed.), On Understanding Poverty (pp. 187-199). New York: Basic Books.

López, N. (2002). Hopeful girls, troubled boys : race and gender disparity in urban education. New York: Routledge.

Louie, V. (2001). Parents' Aspirations and Investment: The Role of Social Class in the Educational Experiences of 1.5- and Second-Generation Chinese Americans. Harvard Educational Review, 71(3), 438-474.

Louie, V. S. (2004). Compelled to excel : immigration, education, and opportunity among Chinese Americans. Stanford, Calif.: Stanford University Press.

Lundy, G. F., \& Firebaugh, G. (2005). Peer Relations and School Resistance: Does Oppositional Culture Apply to Race or to Gender? Journal of Negro Education, 74(3), 233-245.

MacLeod, J. (1995). Ain't No Makin' It: Aspirations and Attainment in a Low-income Neighborhood. Boulder: Westview Press.

Maira, S. (2002). Desis in the house: Indian American youth culture in New York City. Philadelphia: Temple University Press.

Massey, D., Charles, C., Lundy, G. F., \& Fischer, M. (2003). The Source of the River: The Social Origins of Freshmen at America's Selective Colleges and Universities. Princeton, NJ: Princeton University Press. 
McCarthy, C. (Ed.). (1993). Race, Identity, and Representation in Education. New York: Routledge.

McWhorter, J. (2001). Losing the Race: Self-Sabotage in Black America. New York: Perennial.

Mehan, H., Hubbard, L., \& Villanueva, I. (1994). Forming Academic Identities: Accommodation without Assimilation among Involuntary Minorities. Anthropology \& Education Quarterly, 25(2), 91-117.

Merton, R. (1968). Social Theory and Structure. New York: Free Press.

Mickelson, R. (2001). Subverting Swann: First- and Second-Generation Segregation in the Charlotte-Mecklenburg Schools. American Educational Research Journal, 38(215-252).

Mickelson, R. A. (1990). The Attitude-Achievement Paradox Among Black Adolescents. Sociology of Education 63(1), 44-62.

Mickelson, R. A., \& Velasco, A. E. (2006). Bring it On! Diverse Responses to "Acting White" Among Academically Able Black Adolescents. In E. Horvat \& C. O'Connor (Eds.), Beyond Acting White: Reassessments and New Directions in Research on Black Students and School Success. New York: Rowan and Littlefield.

Mirza, H. S. (1999). Black Masculinities and Schooling: a black feminist response. British Journal of Sociology of Education 20(1), 137-147.

Murrell Jr, P. C. (1994). In search of responsive teaching for African American males: An investigation of students'. Journal of Negro Education, 63(4), 556.

Murrell Jr, P. C. (2000). Community Teachers: A Conceptual Framework for Preparing Exemplary Urban Teachers. Journal of Negro Education, 69(4), 338.

Murrell, P. C. (2002). African-centered pedagogy : developing schools of achievement for African American children. Albany: State University of New York Press.

Nasir, N. S., \& Hand, V. M. (2006). Exploring Sociocultural Perspectives on Race, Culture and Learning. Review of Educational Research, 76(4), 449-475.

National Center for Education Statistics. (2001). Education Achievement and Black-White Inequality. Washington, D.C.: Department of Education.

National Center for Education Statistics. (2007). Staus and Trends in the Education of Racial and Ethnic Minorities. Washington, D.C.: Department of Education.

National Commission on Teaching and America's Future. (1996). What Matters Most: Teaching for America's Future. New York: Teachers College, Columbia University.

Neckerman, K. M., Carter, P., \& Lee, J. (1999). Segmented Assimilation and Minority Cultures of Mobility. Ethnic and Racial Studies 22(6), 945-965.

Ngo, B., \& Lee, S. J. (2007). Complicating the Image of Model Minority Success: A Review of Southeast Asian American Education.

O'Connor, C. (2001). Making Sense of the Complexity of Social Identity in Relation to Achievement: A Sociological Challenge in the New Millenium. Sociology of Education, Extra Issue, 159-168.

O'Connor, C., Lewis, A., \& Mueller, J. (2007). Researching "Black" Educational Experiences and Outcomes: Theoretical and Methodological Considerations. Educational Researcher, 36(9), 541-552. 
Oakes, J. (1985). Keeping Track: How Schools Structure Inequality. New Haven, CT: Yale University Press.

Ogbu, J. (1978). Minority Education and Caste. New York: Academic Press.

Ogbu, J. (1990). Minority Status and Literacy in Comparative Perspective. Daedalus, 119(2), 141-168.

Ogbu, J. (1991). Immigrant and Involuntary Minorities in Comparative Perspective. In J. Ogbu \& M. Gibson (Eds.), A Comparative Study of immigrant and Involuntary Minorities (pp. 3-33). New York Garland Publishing.

Ogbu, J. (2004). Collective Identity and the Burden of 'Acting White' in Black History, Community, and Education. The Urban Review 36(1), 1-35.

Ogbu, J. U., \& Simons, H. D. (1998). Voluntary and Involuntary Minorities: A CulturalEcological Theory of School Performance with Some Implications for Education. Anthropology and Education Quarterly, 29(2), 155-188.

Osajima, K. (1988). Asian Americans as the Model Minority: An Analysis of the Popular Press Image in the 1960s and 1980s. In G. Y. Okihiro \& J. M. Liu \& A. A. Hansen \& S. Hune (Eds.), Reflections on Shattered Windows: Promises and Prospects for Asian American Studies (pp. 165-174). Pullman: Washington State University Press.

Oyserman, D., Brickman, D., Bybee, D., \& Celious, A. (2006). Fitting in Matters: Markers of In-Group Belonging and Academic Outcomes. Psychological Science, 17(10), 854-861.

Oyserman, D., Brickman, D., \& Rhodes, M. (2007). Racial-Ethnic Identity: Content and Consequences for African American, Latino, and Latina Youths. In A. Fuligni (Ed.), Contesting Stereotypes and Creating Identities: Social Categories, Social Identities, and Educational Participation (pp. 91-114). New York: Russell Sage Foundation.

Park, K. (1999). I really do feel I'm 1.5: The constructuion of self and community by young Korean Americans. Amerasia Journal, 25(1139-163).

Parker, L., Deyhle, D., \& Villenas, S. A. (Eds.). (1999). Race Is-- Race Isn't: Critical Race Theory and Qualitative Studies in Education Boulder, CO: Westview Press.

Pattillo-McCoy, M. (1999). Black picket fences : privilege and peril among the Black middle class. Chicago: University of Chicago Press.

Perlmann, J., \& Waldinger, R. (1997). Second Generation Decline? Children of Immigrants, Past and Present - A Reconsideration. International Migration Review 31(4), 893-922.

Perry, P. (2002). Shades of white : white kids and racial identities in high school. Durham, NC: Duke University Press.

Phinney, J. S. (1991). Ethnic Identity and Self-Esteem: A review and integration. Hispanic Journal of Behavioral Sciences, 13(2), 193-208.

Pollock, M. (2004). Colormute: race talk dilemmas in an American school. Princeton: Princeton University Press.

Portes, A., \& Bach, R. L. (1985). Latin journey: Cuban and Mexican immigrants in the United States. Berkeley: University of California Press.

Portes, A., Fernández-Kelly, P., \& Haller, W. (2005). Segmented assimilation on the ground: The new second generation in early adulthood. Ethnic \& Racial Studies, 28(6), 1000-1040. 
Portes, A., \& Rumbaut, R. G. (2001). Legacies : the story of the immigrant second generation. Berkeley

New York: University of California Press ;

Russell Sage Foundation.

Portes, A., \& Zhou, M. (1993). The New Second Generation: Segmented Assimilation and its Variants. The Annals of the American Academy 530, 74-96.

Purkayastha, B. (2005). Negotiating ethnicity : second-generation South Asian Americans traverse a transnational world. New Brunswick, N.J.: Rutgers University Press.

Quiroz, P. A. (2001). The Silencing of Latino Student "Voice": Puerto Rican and Mexican Narratives in Eighth Grade and High School. Anthropology and Education, 32(3), 326-349.

Ramakrishnan, S. K. (2004). Second-Generation Immigrants? The â€œ2.5 Generationâ€ in the United States. Social Science Quarterly (Blackwell Publishing Limited), 85(2), 380-399.

Rist, R. (1977). The Urban School: Factory for Failure: A Study of Education in American Society. Cambridge, MA: MIT Press.

Roscigno, V. J. (1998). Race and the Reproduction of Educational Disadvantage. Social Forces, 76(3), 1033.

Rumbaut, R. (2004). Ages, Life Stages, and Generational Cohorts: Decomposing the Immigrant First and Second Generations in the United States. International Migration Review 38(3), 1160-1205.

Sager, H. A., \& Schofield, J. W. (1984). Integrating the Desegregated School: Problems and Possibilities. Advances in Motivation and Achievement, 1, 203-241.

Sassler, S. L. (2006). School Participation Among Immigrant Youths: The Case of Segmented Assimilation in the Early 20th Century. Sociology of Education, 79(1), 1.

Sellers, R. M., Chavous, T. M., \& Cooke, D. Y. (1998). Racial Ideology and Racial Centrality as Predictors of African American College Students' Academic Performance. Journal of Black Psychology, 24(1), 8-27.

Sewell, T. (1997). Black masculinities and schooling : how Black boys survive modern schooling. Stoke on Trent, England: Trentham Books.

Slaughter-Defoe, D. T., Nakagawa, K., Takanishi, R., \& Johnson, D. J. (1990). Toward Cultural/Ecological Perspectives on Schooling and Achievement in African- and Asian-American Children. Child Development, 61, 363-383.

Solorzano, D. G., \& Ornelas, A. (2004). A Critical Race Analysis of Latina/o and African AmericanAdvanced Placement Enrollment in Public High Schools. High School Journal, 87(3), 15-26.

Stanton-Salazar, R. D. (1997). A Social Capital Framework for Understanding the Socialization of Racial Minority Children and Youths. Harvard Educational Review, 67(1), 1-40.

Stanton-Salazar, R. D. (2001). Manufacturing Hope and Despair : The School and Kin Support Networks of U.S.-Mexican Youth. New York: Teachers College Press.

Suárez-Orozco, C., \& Suárez-Orozco, M. M. (1995). Trans-formations : immigration, family life, and achievement motivation among Latino adolescents. Stanford, Calif.: Stanford University Press. 
Sue, S., \& Okazaki, S. (1990). Asian Americans' Educational Achievement: A Phenomenon in Search of Explanation. American Psychologist, 45(8), 913-920.

Sussman, N. (2000). The Dynamic Nature of Cultural Identity Throughout Cultural Transitions: Why is Home Not So Sweet. Personality and Social Psychology Review, 4(4), 355-373.

Swidler, A. (1986). Culture in Action: Symbols and Strategies. American Sociological Review 51(2), 273-286.

Torres-Guzman, M. E. (2007). Dual Language Programs: Key Features and Results. In O. Garcia \& C. Baker (Eds.), Bilingual Education: An Introductory Reader (pp. 5063). Clevedon, England: Multilingual Matters.

Tuan, M. (1999). Neither Real Americans nor Real Asians? Multigeneration Asian Ethnics Navigating the Terrain of Authenticity. Qualitative Sociology, 22(2), 105125.

Tyson, K., \& Darity, J. W. (2005). It's Not "a Black Thing": Understanding the Burden of Acting White and Other Dilemmas of High Achievement. American Sociological Review, 70(4), 582-605.

Valenzuela, A. (1999). Subtractive schooling : issues of caring in education of U.S.Mexican youth. Albany: State University of New York Press.

Waldinger, R., \& Feliciano, C. (2004). Will the new second generation experience 'downward assimilation'? Segmented assimilation re-assessed. Ethnic and Racial Studies 27(3), 376-403.

Warikoo, N. (2005). The Cultural Worlds of Second Generation Teenagers in London and New York City. Harvard University, Cambridge, MA.

Waters, M. C. (1996). The Intersection of Gender, Race, and Ethnicity in Identity Development of Caribbean American Teens. In B. J. Ross \& N. Way (Eds.), Urban Girls: Resisting Stereotypes, Creating Identities. New York: New York University.

Waters, M. C. (1999). Black identities : West Indian immigrant dreams and American realities. New York and Cambridge, MA: Russell Sage Foundation and Harvard University Press.

Weber, M. (1968). Ethnic Grouips. In G. Roth \& C. Wittich (Eds.), Economy and Society. Berkeley: University of California.

Willie, S. S. (2003). Acting Black: College, Identity, and the Performance of Race (First Edition ed.): Routledge.

Willis, P. E. (1977). Learning to labour : how working class kids get working class jobs. Farnborough, Eng.: Saxon House.

Wimmer, A. (2007). How (not) to think about ethnicity in immigrant societies: A boundary making perspective (Working Paper No. 44). Oxford: ESRC Centre on Migration, Policy and Society, University of Oxford.

Wong, P., Lai, C. F., \& Nagasawa, R. (1998). Asian Americans As a Model Minority: Self-perceptions and Perceptions by Other Racial Groups. Sociological Perspectives, 41(1), 95-118.

Yon, D. (2000). Elusive Culture: Schooling, Race, and Identity in Global Times. Albany, NY: SUNY Press.

Yosso, T. (2005). Whose culture has capital? A critical race theory discussion of community cultural wealth. Race, Ethnicity \& Education, 8(1), 69-91. 
Zhou, M. (1997). Segmented Assimilation: Issues, Controversies, and Recent Research on the New Second Generation. International Migration Review, 31(4), 975-1008. Zhou, M., \& Bankston, C. L. (1998). Growing up American : how Vietnamese children adapt to life in the United States. New York: Russell Sage Foundation.

ENDNOTES

${ }^{1}$ Here and throughout this review, we refer primarily to results gathered from students in public (and primarily urban) school districts.

${ }^{2}$ Our usage of the terms "subtractive" and "additive” differ somewhat from their connotations in the social psychological and assimilation literature focusing on cultural shifts as individuals move from their communal to "foreign” contexts. In numerous psychological studies, "subtractive” refers more to those who would lose touch with their native/home culture identity and compelled to assimilate, and "additive” refers to feeling closer to the host/dominant cultural identity, although with some maintenance of one's cultural heritage (Sussman, 2000).

${ }^{3}$ We make no presumptions about consistency or "hard" linkages among cultural beliefs, values, and behavioral patterns. Culture may contain contradictory elements and hence certain social actions or practices may not necessarily correspond to the values or norms to which various groups subscribe. Our entire conceptualization of culture takes into account its dynamic and temporal nature. In other words, the bases of shared meaning and practices may change according to the social setting and the historical moment. We discuss the variability of culture's dimensions later in the paper.

${ }^{4}$ The distinction of refugees as a separate minority group did not occur until twenty years after Ogbu's first formulation of CET, when Ogbu and colleagues refined the theory and expanded the narrow parameters of their original concepts (Ogbu \& Simons, 1998). In 
the revised typology guest workers/migrants, undocumented workers, binationals, and refugees are all defined as neither voluntary nor involuntary minorities. Nonetheless, like voluntary minorities, these groups are described as maintaining a "tourist attitude" towards the U.S. and behaving as cultural rationalists who behave and speak as they need to thrive economically.

${ }^{5}$ Psychologist Robert Sellers and his colleagues specify four specific dimensions of racial ideology: "assimilationist,” "humanist,” "nationalist ” and“ oppressed minority.” An assimilationist views him/herself as primarily an American and attempts to enter, as much as possible, into the mainstream. Humanists view all humans as similar and do not think in terms of social categories such as race, ethnicity, class, or gender. Nationalists perceive their race as unique and are inclined to participate primarily in social, political, and economic activities that pertain to his/her racial heritage. One who holds the oppressed minority (or "minority") ideology tends to view the similarities and connections in experiences among theirs and other similarly subordinated groups in society (Sellers, Chavous, \& Cooke, 1998: 27-28).

${ }^{6}$ The one exception to this racialized understanding of rebellion through popular culture is Donna Gaines' study of White working class teenagers in Bergenfield, New Jersey during the late 1980s, published 15 years ago. Gaines skillfully describes the youth culture among White, working class young adults who have lost optimism for the future, and have seen a spate of friends commit suicide, interweaving their styles and music tastes (Gaines, 1991). 